\title{
6. Exkurs: Internationale Kooperation European Psychiatric Association (EPA): Zurück in die Zukunft!
}

\author{
Cécile Hanon, Nikolina Jovanovic, Olivier Andlauer and Martina Rojnic Kuz- \\ man
}

\section{Vorbemerkung der Herausgeber}

Wir erachten die Mitarbeit gerade von jungen Ärzten im Fachgebiet der Psychiatrie und Psychotherapie für wichtig: Sowohl auf nationaler, aber auch auf internationaler Ebene gibt es hierfür eine Reihe von Möglichkeiten, die Ihnen dabei helfen können, Ihren Horizont zu erweitern. Als Beispiel haben wir für den folgenden Beitrag die Europäische Psychiatrische Vereinigung (EPA) gewählt: Einige in dieser Organisation aktive junge Psychiater und Psychiaterinnen stellen Ihnen zusammen mit Cécile Hanon, der Leiterin des Ausbildungskomitees der EPA, deren für Sie vielleicht interessante Angebote vor und möchten Sie damit zur Mitarbeit ermuntern!

Die EPA bietet gerade für junge Psychiater vielfältige Möglichkeiten, sich innerhalb der psychiatrischen europäischen Fachöffentlichkeit international zu vernetzen.

Die jährlich stattfindende EPA Summer School in Strasbourg ist eine gute Gelegenheit, sich in entspannter Atmosphäre mit jungen Ärzten aus Europa auszutauschen.

Weitere Informationen finden Sie im folgenden Beitrag und können außerdem erfragt werden bei cecile.hanon@eps-erasme.fr. 
The European Psychiatric Association - EPA - is an association that has as its mission improvement of Psychiatry and Mental Health Care in Europe. EPA's activities address the interests of psychiatrists in academia, research and practice throughout all stages of career development.

\section{History and background}

EPA was founded in October 1983 in the library of the Psychiatric Clinic of the University Hospitals of Strasbourg. The founding members were twelve Frenchand German-speaking University Psychiatrists: Professor Manfred Ackenheil † (Munich), Professor Peter Berner + (Vienna), Professor Daniel Bobon † (Liège), Professor Horst Dilling (Lübeck), Professor Henri Dufour † (Marseille), Professor Hans Heimann † (Tübingen), Professor Hans Hippius (Munich), Professor Michel Patris (Strasbourg), Professor Pierre Pichot (Paris), Professor Charles Pull (Luxembourg), Professor Werner Rein (Tübingen) and Professor Léonard Singer + (Strasbourg).

The association was initially given the name "Association of European Psychiatrists (AEP)", and changed to European Psychiatry Association (EPA) in 2008, in order to be in harmony with its international partners.

The objective of the founding members was to establish an Association of French and German Psychiatrists, which would promote European Psychiatry in the fields of research, treatment and teaching, three axes considered to be complementary. In the mind of its founding members, this Franco-German Association was to be the first step towards the creation of an Association gathering psychiatrists from all European countries.

In order to reach these goals, the association gradually set up the organisation of the annual European Congress of Psychiatry, as well as other regular scientific meetings, the publication of a scientific international journal (European Psychiatry), the awarding of research grants and the creation of sections, as working groups corresponding to sub-disciplines in psychiatry.

Nowadays, with active individual members in as many as 81 countries and 36 National Society/Association Members who represent over 77,0 oo European psychiatrists, the European Psychiatric Association is the main association representing psychiatry in Europe.

\section{EPA programme of educational activities}

Within its mission, EPA aims at improving continuing medical education in psychiatry and pays special attention to the younger generation of psychiatrists. It contributes to ensure the best possible training level as well as its harmonisation at European level, while taking into account national specificities of each country.

In order to achieve these goals, the EPA Committee on Education has expanded its domains of action and has defined a programme of educational activities, entitled "EPA Academia for Excellence in European Psychiatry". 
Today, the EPA educational activities are organized around 3 axes:

EPA Academia Educational Courses, which have been organised within the scientific programme of the annual European Congress of Psychiatry since 2002. These courses are tailored to professionals in mental health field willing to access continuing medical education and international training programs, be informed about new scientific data and new medical techniques that are essential for their daily practice.

EPA Academia Itinerant Courses Programme, which is carried out throughout Europe in collaboration with national psychiatric associations and other EPA partners. EPA Itinerant Courses are usually organised during national congresses of psychiatry or as stand-alone events.

EPA Academia Summer School, which was launched in 2011 by Professor Henning Saß, former EPA President and Secretary for Education, with the aim to offer to most promising young psychiatrists from across Europe outstanding teaching on a subject rarely taught in the general curriculum of Psychiatry, which is Comorbidity between mental and physical disorders. The Summer School aims at developing the participants' ability to recognize comorbidity and provides theoretical and practical lessons on how to manage patients with both physical and mental disorders. Since 2011, four editions of the Summer School were organised, the last one taking place on 29 May - 1 June 2014 in Strasbourg (France), under the auspices of the Secretary General of the Council of Europe, Mr Thorbjørn Jagland. The Faculty of the $4^{\text {th }}$ EPA Summer School consisted of Norman Sartorius, Switzerland; Christoph Lauber, Switzerland; Albert Diefenbacher, Germany and Henk Parmentier, United Kingdom.

$\mathrm{A} 4^{\text {th }}$ axe of work is ongoing, and will be the implementation of Online Education and eLearning tools. It will allow more people to get educational courses out of the congress venue, with the same label of quality and excellence ensured by our association.

\section{Special attention to Early Career Psychiatrists}

Since last ten years, EPA has been focusing more and more on the needs of young psychiatrists. A special scientific track dedicated to psychiatrists at early stage of career, "Young Psychiatrists Program", was launched during the EPA congress in Geneva in 2004. The organising committee of this track became the Early Career Psychiatrists Committee (ECPC) in 2009 and implements various activities and projects to improve professional development for young psychiatrists.

The main activities consisted of the organization of a specific programme during the EPA congress, tailored for young psychiatrists (conversations, court debates, symposia and workshops) and the possibilities of scholarships and travel grants, research prize.

Since 2011, the activities of the ECPC expanded towards an action plan aimed to identify and address problems concerning early career psychiatrists in the various sectorial activities as well as to contribute to promote the professional development in Europe. 
Subsequently, 4 “Task forces” were formed: research, publication, meetings \& associations and professional development

The task force on research coordinates international research projects conducted by EPA ECPC at the European level, facilitate the involvement in research activities of young prominent scientists from other international associations and from previous winners of EPA awards, explore other possibilities to raise funds from non-governmental bodies and from European Commission and disseminate the results of the research projects in major European conferences and on highquality scientific journals. The success of this task force is reflected in a number of successful projects that were subsequently published in relevant journals, as well as in obtaining the first EPA ECPC funding from one official EU funding Agency (eg. www.psylog.eu).

The task force on publication coordinates the production of papers and books relevant for early career psychiatrists. A number of important papers and even books were released thanks to the activity of this task force.

The task force on meetings \& associations organises events or workshops on topics relevant for early career psychiatrists, and represents the ECPC at other national and international meetings.

The task force on professional development coordinates actions directed to the training of ECPs such as development e-learning materials/educational modules and conference presentations, advertises and helps to organize EPA educational activities, promotes the exchange of the ECPs among different European psychiatric centres and countries.

In 2014 the EPA-ECPC launched a new project entitled The Gaining Experience Programme. The aim is to promote intercultural professional exchange of knowledge and experience among young psychiatry specialists under 40 years of age and/or 5 years after passing the specialist exam from any European country (WHO definition of Europe). The program offers short observership placements in various psychiatric institutions across Europe, thus allowing applicants to broaden their clinical and/or research and/or teaching skills and knowledge, and become familiar with different mental health systems in Europe. The pilot phase (2014-2015) includes four placements in Switzerland, Israel, UK and Germany, with scholarships for successful applicants to help with travel, accommodation and other expenses.

\section{Conclusion}

At the time of the great upheavals in terms of knowledge, scientific advances, velocity of learning, related to the globalisation of knowledge, the digital revolution and its avatars, young psychiatrists must ride the wave ... and EPA provides adequate "boards"!

The transmission and sharing of knowledge, both theoretical and practical, are organized and diffused differently, accelerate without doubt, but should not nonetheless lose in quality. Excellence acquired by the EPA faculty over the years remains a safe value, a value that is renewed and enriched.

The younger generations are the crucible of the future of our specialty, which is constantly moving, and EPA accompanies them throughout the trip. 
V Fachteil Psychiatrie

As a former member of the EPA ECPC and current chair of the EPA Committee of Education, I have only one hope: that many of you decide to join our beautiful association and participate in its future!

\section{Literature}

www.europsy.net

Fiorillo A, Calliess I, Sass H (2012) How to Succeed in Psychiatry: A Guide to Training and Practice. Wiley publications Hoboken, NJ 